\title{
Effect of Derma New Gel in signs of skin aging
}

\author{
Dr. Jadhav U. B. , Dr. Ikkar R. B. \\ Associate Professor Kriyasharir, Shri Saptashrungi Ayurved Mahavidyalaya, Nashik.
}

\begin{abstract}
Abstact:-
Aim of Ayurveda is not only cure the disease but also prevent the disease. In preventive measures 'Jara Chikitsa' is the specialty of Ayurveda which is described in Ashtang Ayurveda and it is mainely concerned to prolong young age i.e. to delayed signs of aging.

Skin is the first body part to show the signs of age. The present study deals with "To Study The effect of Derma-New Gel in signs of skin aging. Three Ayurvedic herbs are used while making Gel Kumari (aloe vera), Taruni (rose) and Kumkuma (saffron). In samhita granthas their tvachya, varnya, kustaghna etc properties are already mentioned. Using these references this clinical trial is done and results obtained are described with proper examination.
\end{abstract}

Keywords:- Skin aging signs, effect of derma New Gel ( Aloe vera svarasa, Rose water, Saffron powder )

\section{Introduction -}

Ayurveda is the science of life. In definition of Ayurveda mentioned that,

हिताहितं सुखं दु:खं अयुस्तस्य हितहितं।

मानं च तच्च यत्रोक्तं आयुर्वेद स उच्यते॥ (च. सु. १/४१)

Science is designated as Ayurveda where advantages and disadvantages as well as happy and unhappy life along with what is good and what is bad for life, is measured and life itself is described. Jara chikitsa is part of Ashtang Ayurveda mainly related to prevent aging .

Skin is the first body part to show the signs of age. Healthy age-related skin changes are inevitable and include thinning, sagging, wrinkling and the appearance of age spots, broken blood vessels and areas of dryness.

Derma New Gel is the gel prepared by using combination of three Ayurvedic hurbs which having Tvachya, Varnya, Rasayana Kushtaghna and wond healing property. In this work Kumari svarasa, keshar powder and rose water used in Gel formation. Effect of Derma New Gel in signs of skin aging studied in single case briefly.

Aims - To Study the Effect of Derma - New Gel in signs of skin aging.

\section{Objectives -}

1. To study effect of derma new gel in fine lines and wrinkles.

2. To study effect of derma new gel in large pores.

3. To study effect of derma new gel in pigmentation.

4. To study effect of derma new gel in dryness of skin.

\section{Materials and Methods - Ayurvedic herbs used -}

\author{
Kumari - Aloe vera \\ Lattine Name - Aloe Berbadensis \\ Family - Liliaceae
}


Part use - Aloe pulp swarasa.

Taruni - Rose

Latine name - Rosa centifolia

Family - Roseceae

Part use - Ark of petals.

Kumkuma - Saffrone

Latin name - Crocus sativus

Family- iridaceae

Part use - punkesar

Material used in formation of Gel -

Carbapol 940, TEP, preservatives (Methyl paraben, Propyl paraben, Sodium benzoate)

Aloe vera pulp, Rose water, Saffron powder, Blebder, Water bath for indirect heat, Standard pH paper, Flask.

\section{Method of Preparation of Gel:}

Aloe Vera pulp is extracted from leaves of Aloe Vera excluding green part of it. Aloe vera pulp is crushed in mixture and grinder to make aloe vera juice. The $150 \mathrm{gm}$ juice is taken in flask, $150 \mathrm{gm}$ rose water and 0.5 gm saffron powder added in to it. The mixture is heated indirectly in water bath for 5 to 10 minutes. Carbapol $940(1-5 \%)$ added slowly with a small spoon upto gel like consistency appears and mixed with a blender. About 5 gm Carbapol 940 used for making gel like consistency. pH of gel like form is checked with $\mathrm{pH}$ paper ( $\mathrm{pH}$ 6). TEP $(1-2 \%)$ added in gel form drop wise and mixed well to make uniform gel. Finally $\mathrm{pH}$ of gel checked which is of neutral in nature $(\mathrm{pH} 7)$. The all three preservatives like methyl paraben $(3$ $\mathrm{mg}$ ), propyl paraben $(5 \mathrm{mg}$ ) and sodium benzoate $(5 \mathrm{mg})$ are added in aloe vera gel form and stirred well with blender. Gel is allowed to cool down and packed in $75 \mathrm{gm}$ packing bottle. Test is done on selected parts of body of volunteer and volunteer is instructed for restrict the use of moisturisers, creams from 1 day before examination to throughout the treatment i.e. for 1 months.

\section{Observations of product used :-}

\begin{tabular}{|c|c|c|}
\hline Sr. No & End Product & Observation \\
\hline 1. & Temperature & $37^{\circ} \mathrm{C}$ \\
\hline 2. & Colour & Light orange \\
\hline 3. & Consistency & Gel \\
\hline 4. & Appearance & Semitransparent \\
\hline 5. & Reaction & Neutral \\
\hline 6. & Smell & Mild pungent \\
\hline
\end{tabular}

\section{Description of Final Product:}

- Type of formulation obtained: Gel

- Panchbautik parikshan-

○ Shabda - Nil.

- Sparsha - Smooth.

○ Roopa - Light orange semitransparent.

- Rasa - Nil.

○ Gandha - Mild pungent.

○ Transperency - Semitransparent.

○ $\mathrm{pH}-7.0$

- Intial weight -300 gms. $\quad$ Final weight obtained -270 gms 
Dr. Jadhav U. B., International Journal of Ayurvedic \& Herbal Medicine 8(4) July.-August. 2018 (3283-3289)

Weght loss - 30gms.
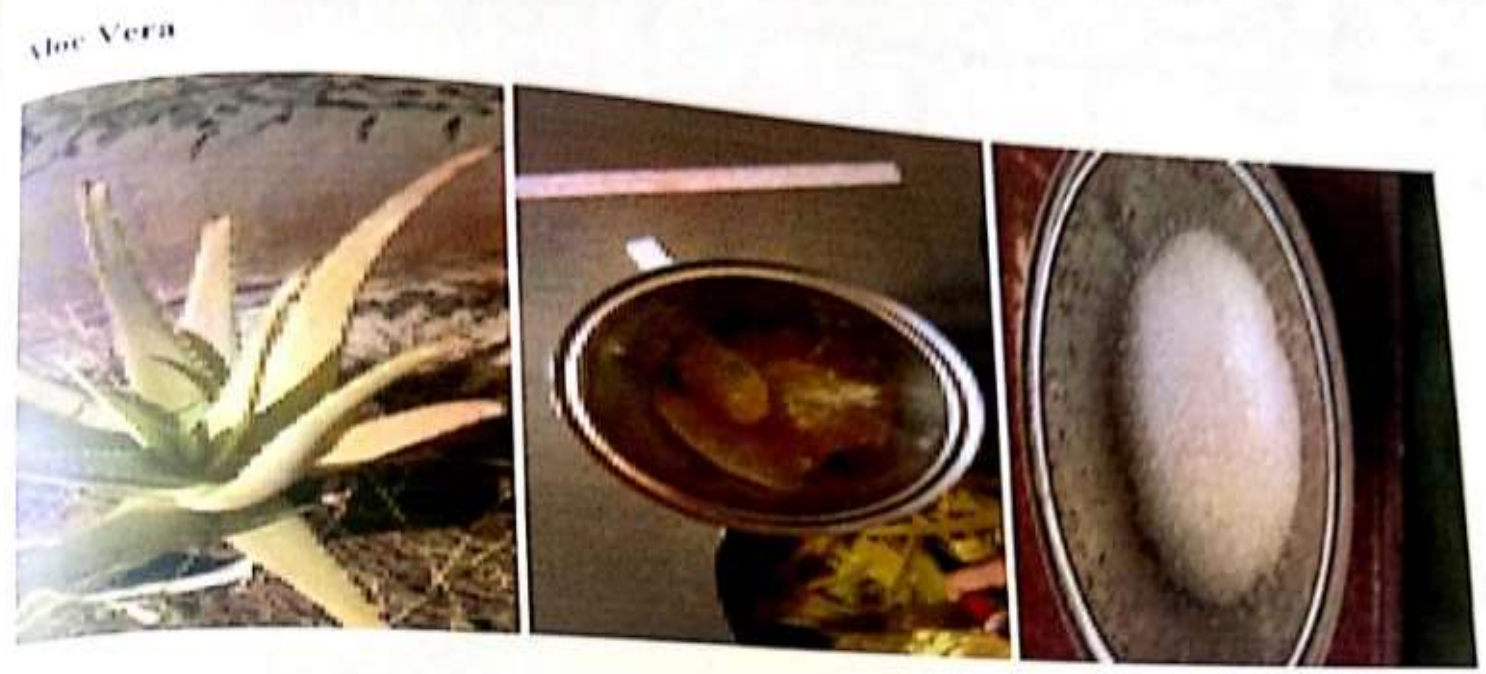

Saffron and Rose water
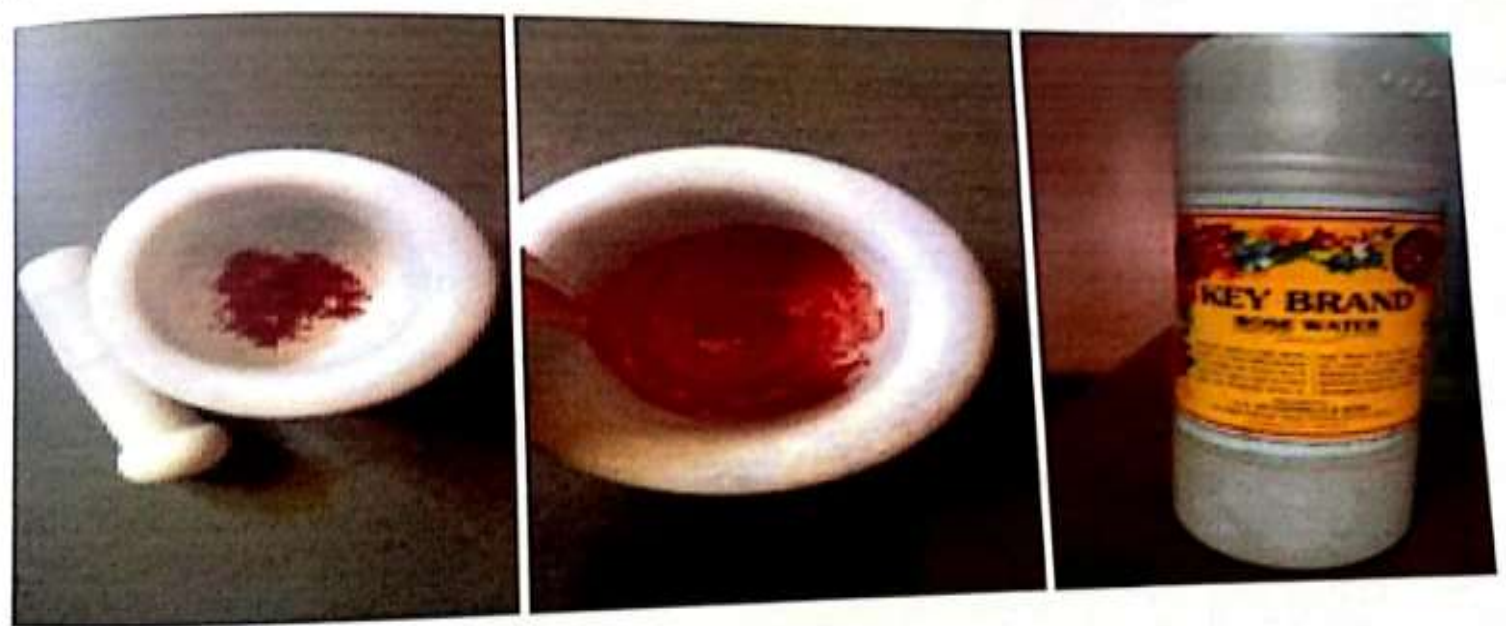

TEA, Carbapol 940 and $\mathrm{pH}$ paper

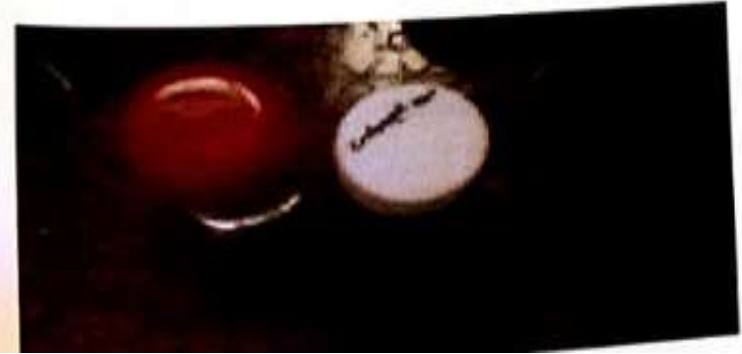

Reason for weight loss -1 . Heating of aloe vera juice solution.

2. Gel is sticked to container.

\section{Examination of patient}

Weight of volunteer is measured by weighing machine.

Temperature is measured with the help of clinical thermometer.

Temperature of axillary region is measured.

Blood pressure of volunteer is measured with the help of Sphygmomanometer.

Pulse is measured by palpation method. Radial pulse is measured for one minute

Tongue is examined by Darshan pariksha. 
Questions are asked to volunteer for Mala, Mutra, Kshudha, Diet, Rasabhiruchi, Exercise, addictions.

Special skin examination is done before and after result to be noted.

Test is done on selected parts of body of volunteer and volunteer is instructed for restrict the use of moisturisers, creams from 1 day before examination to throughout the treatment i.e. for 1 months.

Patient is advised to prevent consumption of spicy meal. Katu, amla, lavan ahar. Ushnaha.

Avoid stress.

Exercise regularly.

Internal medicine - Paripathadi Kadha 2 tsp twise aday wth $1 / 2$ cup of water.

Kushmad avleha 1 tsp at rasayan kala.

External use - Derma new Gel application on face and hands twice a day after proper cleaning with water.

\section{Results and Observations:}

\section{Case Record form}

Name of volunteer: Anjirabai Gopichand Wadile

Address: Utkarsh colony, Sakri road, Dhule.

Age: 63 years

Sex: Female

Case No.: 1

Occupation: Housewife

Date: $15 / 11 / 2016$

Habitat: Dhule

Addiction - no

\section{Present Complaint If Any:}

Wrinkles, fine lines on hands and all over face since 2 years.

General examination -

Nadi- Pittapradhan

Mutra - Samyak

Kshudha - Kshudhamandya

Akriti - Madhyam

Mala - Samyak

Jivha - Sshad saam

Druk - NAD

Diet: Mix

Rasabhiruchi : Amla Lavan Katu abhilashi

Type of Skin - Dry skin

\section{Special Skin Examination:}

Skin texture - Rough

Acne and sequel - No acne and sequel.

Hypopigmentation - NO

Oedema - NO
Colour - Normal

Pigmentation - Black spots

Hirsutism - NO

Skin tone - Decreased

\section{Signs of skin aging of face}

\begin{tabular}{|c|l|c|c|}
\hline $\begin{array}{c}\text { Sr. } \\
\text { No. }\end{array}$ & \multicolumn{1}{|c|}{ Signs } & $\begin{array}{c}\text { Before } \\
\text { treatment }\end{array}$ & $\begin{array}{c}\text { After } \\
\text { treatment }\end{array}$ \\
\hline 1. & Fine lines - around eye, chick, forehead & Severe +++ & Moderate ++ \\
\hline 2. & Wrinkles - all over the face hands more on forehead & Severe +++ & Moderate ++ \\
\hline 3. & Pigmentation - blackish pigmentation on cheek & Mild + & Mild \\
\hline 4. & Sagging - present at maxillary region & Moderate ++ & Moderate ++ \\
\hline 5. & $\begin{array}{l}\text { Dryness of skin - all over dry skin. Scratch test +ve and there is } \\
\text { no much oil on tissue paper }\end{array}$ & Severe +++ & Mild + \\
\hline 6. & Large pores & Moderate ++ & Mild + \\
\hline
\end{tabular}



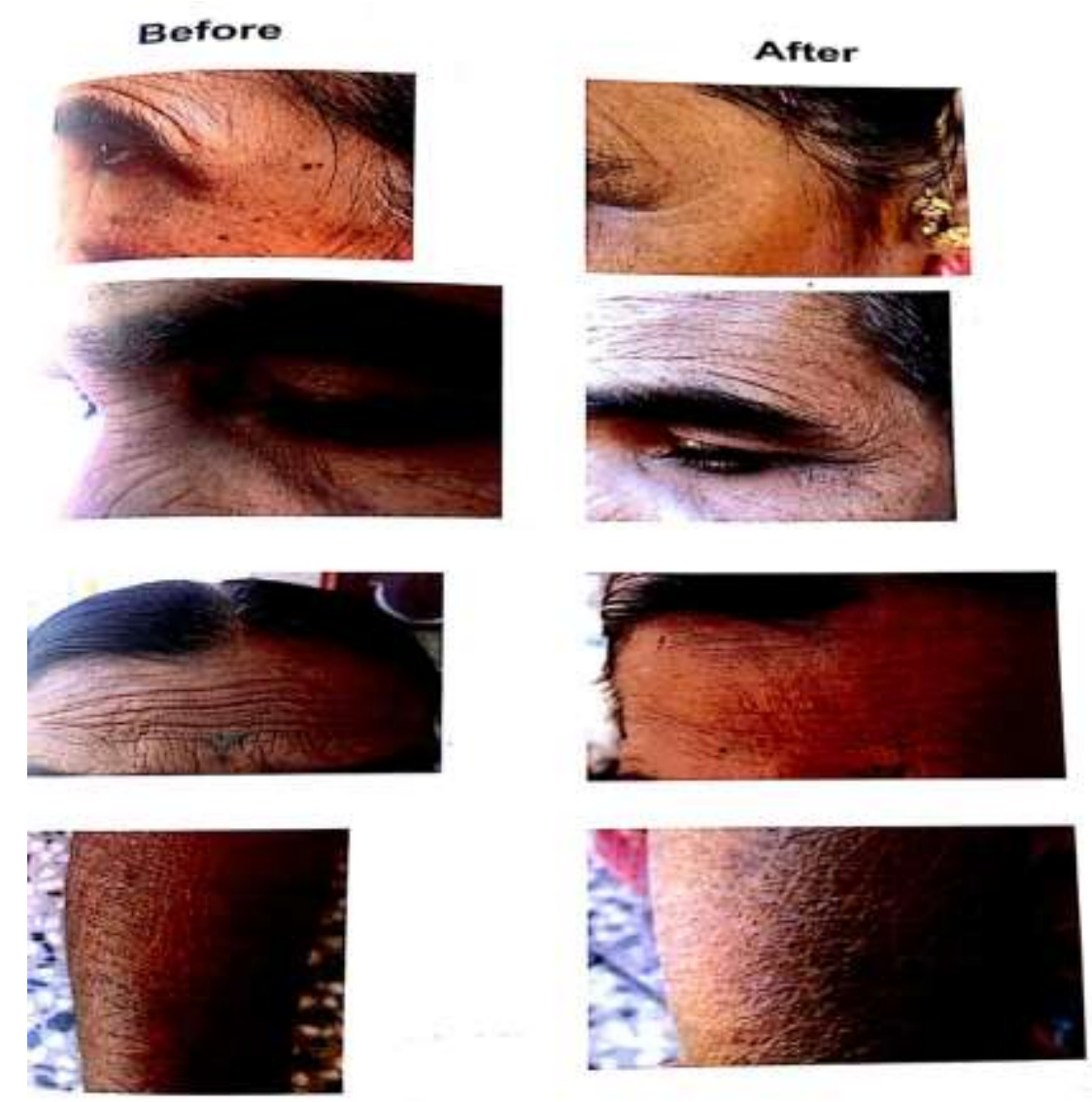

\section{Results -}

Fine lines, wrinkles, dryness and large pores are decreased significantly while pigmentation reduced slightly and sagging has no effect after use of Derma New gel for 1 month.

\section{Discussions: (Mechanism of action)}

Synonyms of aloe vera itself are Ajara, Amara. Aloe vera has mukhyakarma Rasayan karma i.e. has power of Rejuvenation of cells, work in diseases of Pitta, Rakta and Skin. It has excellent wound healing property.

The gel / mucilage is wound healing agent in its fresh state scientific evidence of aloe wound healing property was first documented in 1935 .

Aloe stimulates fibroblast and epithelial cells growth, induces lectin like responses in human cells and promote neuron like cell growth.

According to Ayurveda cause of vali i.e. early wrinkles is due to pittapradhan dosha prakriti and aloe is very good Pittashamak property and specifically work on pitta, Rakta, and twacha.

Taruni Ramtaruni - It has Laghu. Snigdha guna. Main function of it is Varnya, It is blood purifier. Used in Pittavikar and Raktavikar. It pacifies action of all the elevated Tridoshas. Use in skin diseases, all types of leprosy, pacifies Ushna and Tkshna guna of Pitta. Help to improve complexion and glow of skin. It released stress.

\section{Saffron}

Karma - It is used in Skin Diseases like Leprosy, pigmentation. It has excellent wound healing property. It increases complexion of skin. It removes pigmentation of all type and maintained homogenous color of skin. 
All above references shows that all three ingredients in this Gel are Pittashamak, twachya, all are having Snigdha guna. Aloe and Rose improve moisture content of skin and decrease aging sigs i.e. wrinkles, dryness fine lines. Saffron mainly act on pigmentation and improve skin color.

\section{Clinical Indication-}

Dry skin, Wrinkles and fine lines, Pigmentation ,Melasma, Under eye black circles

\section{Contraindications-}

No such contraindications are there.

\section{Problems faced during preparation -}

During preparation though expected ph reached. Consistency Sims to be more liquid than that of gel but when that cooled down it converts in to gel form. So that observing ph and trial and error method amount of carbapol 940 is decided.

\section{References -}

1. Bhavprakash Nighantu, V. Ayurved series 28, Chokhamba prakashan, commented by Dr. K. C. Chunekar, Edited by Dr. G. S. Pandey, Sutra - 229,230, Page no - 419.

2. Kaiyadev Nighantu, Pathyapathyavibodhak, Acharya Priyavat Sharma, Guruprasad Sharma, Jykrushnadas ayurved granthamala 30, Chokhamba oriantalia, sutra - 1638-1640, Page no - 648.

3. Rajnighantu of Pandit Narhari, Krushnadas ayurved series 5, vyakhyakar- Dr. Indradev Tripathi, Krushnadas academy Varanasi 1998, sutra- 49, page no.- 114.

4. Dhanvantari Nighantu, shri thakur Prasad memorial series 2, Edited by Jharkhandey Ojha and Umapati Mishra, kasha hindu vishvavidyalaya Varanasi, sutra- 133, Page no.- 261

5. Shaligram Nighantu, Pushpavarga, Khemraj ratnakar antargatau saptambhag, Page no - 370

6. Madanpalnighantu, vaidyaratna ayurveddharak vaiyapanchanan pandit ramprasad vaidya upadhyayraj vaidyapatiyalavirchit bhashatatvaprakashininam hinditikasahit, Khemraj shrikrushnadas Prakashan, sutra - 14, Page no. 79

7. Dhanvantari Nighantu, shri thakur Prasad memorial series 2, Edited by Jharkhandey Ojha and Umapati Mishra , kasha hindu vishvavidyalaya Varanasi, sutra- 11, Page no. 139 